\title{
Comparison of range of commercial or primary care led weight reduction programmes with minimal intervention control for weight loss in obesity: Lighten Up randomised controlled trial
}

\author{
(c) $)$ (1) \& 8 OPEN ACCESS
}

Kate Jolly clinical senior lecturer in public health and epidemiology ${ }^{1}$, Amanda Lewis NIHR NSPCR research fellow ${ }^{1}$, Jane Beach health visitor adviser ${ }^{2}$, John Denley associate director of public health ${ }^{3}$, Peymane Adab clinical senior lecturer in public health ${ }^{1}$, Jonathan J Deeks professor of biostatistics ${ }^{1}$, Amanda Daley senior lecturer in health psychology ${ }^{1}$, Paul Aveyard senior lecturer in health psychology $^{1}$

\footnotetext{
${ }^{1}$ School of Health and Population Sciences, University of Birmingham, Birmingham B15 2TT, UK; ${ }^{2}$ Nursing and Midwifery Council, 23 Portland Place, London W1B 1PZ, UK; ${ }^{3} \mathrm{NHS}$ South Birmingham, Birmingham B38 5SR
}

\begin{abstract}
Objective To assess the effectiveness of a range of weight management programmes in terms of weight loss.

Design Eight arm randomised controlled trial.

Setting Primary care trust in Birmingham, England.

Participants 740 obese or overweight men and women with a comorbid disorder identified from general practice records.

Interventions Weight loss programmes of 12 weeks' duration: Weight Watchers; Slimming World; Rosemary Conley; group based, dietetics led programme; general practice one to one counselling; pharmacy led one to one counselling; choice of any of the six programmes. The comparator group was provided with 12 vouchers enabling free entrance to a local leisure (fitness) centre.

Main outcome measures The primary outcome was weight loss at programme end (12 weeks). Secondary outcomes were weight loss at one year, self reported physical activity, and percentage weight loss at programme end and one year.

Results Follow-up data were available for 658 (88.9\%) participants at programme end and $522(70.5 \%)$ at one year. All programmes achieved significant weight loss from baseline to programme end (range $1.37 \mathrm{~kg}$ (general practice) to $4.43 \mathrm{~kg}$ (Weight Watchers)), and all except general practice and pharmacy provision resulted in significant weight loss at one year. At one year, only the Weight Watchers group had significantly greater weight loss than did the comparator group (2.5 (95\% confidence interval 0.8 to 4.2$) \mathrm{kg}$ greater loss,). The commercial programmes
\end{abstract}

achieved significantly greater weight loss than did the primary care programmes at programme end (mean difference 2.3 (1.3 to 3.4$) \mathrm{kg}$ ). The primary care programmes were the most costly to provide. Participants allocated to the choice arm did not have better outcomes than those randomly allocated to a programme.

Conclusions Commercially provided weight management services are more effective and cheaper than primary care based services led by specially trained staff, which are ineffective.

Trial registration Current Controlled Trials ISRCTN25072883.

\section{Introduction}

The World Health Organization has described the increase in obesity worldwide as a "global epidemic,"1 and it is associated with several chronic medical conditions. ${ }^{2}$ Obesity is now very common - for example, almost a quarter of the population of England are now classified as obese, ${ }^{3}$ as defined by the WHO's criterion of a body mass index of 30 or above. ${ }^{1}$

Guidelines recommend that primary care physicians in England should identify people with obesity and offer clinical management, ${ }^{4}$ but few options for treatment exist in traditional primary care settings. One widely available option is a commercial weight management programme. In some areas, the English National Health Service offers these services free to patients, and some evidence supports the effectiveness of such provision. A randomised trial of 400 overweight and obese adults in the United States showed that people offered two years' 
free use of a commercial weight management service lost 2.0 $\mathrm{kg}$, whereas those offered two consultations with a dietitian and self help resources lost $0.2 \mathrm{~kg}$ at the end of two years. ${ }^{5}$ (These figures were calculated according to intention to treat, using baseline observation carried forward for missing data. Unless otherwise indicated, all figures quoted in this paper use this convention.) Another trial comparing a very similar control group with a different commercially available intervention, which supplied pre-packaged "diet" foods,${ }^{6}$ had similar conclusions, with weight loss at one year of $6.6 \mathrm{~kg}$ versus 0.7 $\mathrm{kg}$. More recently, a trial offering six months' free use of commercial weight loss programmes led to weight loss of 5-6 $\mathrm{kg}$ compared with $0.6 \mathrm{~kg}$ in the control group, who were asked not to try to control their weight. ${ }^{7}$ Thus good evidence shows that commercial weight management services can be effective, but all existing trials investigated the effectiveness of prolonged treatment programmes that are not available in the English NHS nor in many other health systems.

An alternative, potentially widely available, management option for obesity is for primary care teams to treat their obese patients themselves. A well known primary care programme, the Counterweight programme, has shown promising results in an uncontrolled trial. ${ }^{8-10}$ However, a cluster randomised trial showed that weight loss among obese patients offered treatment by primary care teams who had received well planned training in obesity management ( 4.5 hours' total training) was less than 1 $\mathrm{kg}$ and was similar to the weight loss seen in control practices. ${ }^{11}$ Therefore, insufficient evidence exists for the effectiveness of obesity management in primary care.

We therefore investigated the effectiveness of several pragmatic interventions in primary care patients recruited in the English NHS. These included more modest entitlement to free commercial weight loss management programmes, primary care management, and a minimal intervention control.

\section{Methods}

The protocol for the study, describing the study design, is available online. ${ }^{12}$ Lighten Up was a randomised controlled trial with patients individually allocated to one of eight study groups. We compared six weight loss programmes with a minimal intervention comparator group provided with 12 vouchers enabling free entrance to a local leisure (fitness) centre. Three weight loss programmes were provided by commercial operators: Weight Watchers, Slimming World, and Rosemary Conley. Three were provided by the NHS: a group weight loss programme (Size Down) and two primary care

programmes-nurse led one to one support in general practice and one to one support by a pharmacist. The final study arm allowed for participants to choose one of the six interventions.

\section{Population}

Eligible participants were registered with general practices in South Birmingham Primary Care Trust, were aged at least 18 years, and had a raised body mass index recorded in their primary care notes within the previous 15 months. The body mass index threshold for invitation was that which makes them eligible for primary care obesity management services in the NHS and varied according to ethnic group and the presence or absence of comorbidities (box 1). The threshold for invitation for people with no obesity related comorbidity was a body mass index of 30 or above. For people of South Asian ethnicity, this threshold was lower. The general practitioner had to confirm that the patient had no medical contraindications for any of the intervention programmes before a letter of invitation was sent.
We excluded patients if they were unable to understand English or were pregnant. Seventeen practices took part.

Recruitment took place from January to May 2009. Eligible patients were invited to participate in the trial by a standard letter from their general practitioner, which included the patients' information leaflet and a free telephone number for a call centre managing the recruitment and randomisation. The nurses at the call centre provided more information to patients about the trial, collected baseline information, took verbal consent, and randomised patients to the trial arms. The nurses then booked participants into their first treatment session and sent confirmation, along with verification of consent and information on how to withdraw from the trial if they changed their minds. Participants allocated to the general practice, pharmacy, or minimal intervention (comparator) groups were sent details about how to arrange their first session.

We randomised participants from practices with personnel trained to provide the practice based weight management programme $(n=7)$ to all eight arms with a block size of 35 , whereas we randomised people from other practices $(n=10)$ to one of seven groups (excluding general practice) in a block size of 13. An independent statistician prepared two separate randomisation sequences, and, to ensure blinding, the allocations were placed in opaque, consecutively numbered envelopes, which the call centre staff used in order. The block sizes were determined to achieve one to one randomisation across groups, except for the two primary care arms, for which spaces were limited and allocation was in a ratio of 1 to 0.7 compared with the other groups.

\section{Interventions}

The participants allocated to the commercial operators Weight Watchers, Slimming World, and Rosemary Conley had a choice of locations and times for the programme. ${ }^{13-15}$ Participants were provided with vouchers that exempted them from paying for 12 consecutive weeks of the programmes. Each programme was provided in accordance with the respective organisation's guidance and ran continuously, with no set start date; the group leaders were trained by the respective organisations. The trial participants attended alongside people who paid to attend the programmes.

The Size Down Programme is an NHS group based programme led by food advisers recruited from the local community and trained by the dietetics department; sessions took place in various community venues. All members of the group started together and followed a prescribed course of six sessions, with follow-up weighing sessions at nine and 12 weeks. Participants randomised to the general practice or pharmacy arms attended 12 one to one sessions in the general practice or pharmacy. Appointments were made at a time mutually convenient to the participant and the nurse/pharmacist. Staff delivering these programmes had attended a three day training course on weight management in adults delivered by dietitians experienced in the management of obesity. This included key messages on diet and physical activity, doing a behavioural assessment, goal setting, plans for change, dealing with resistance, enhancing motivation, and weight maintenance. It included both practical tasks and informational components.

Participants allocated to the comparator group were sent vouchers for 12 free sessions at a local authority run leisure centre (a council run facility open to all members of the public and usually consisting of a swimming pool, fitness suite, and other sports halls or courts). Participants were not given an appointment to attend and were given no individual advice or 


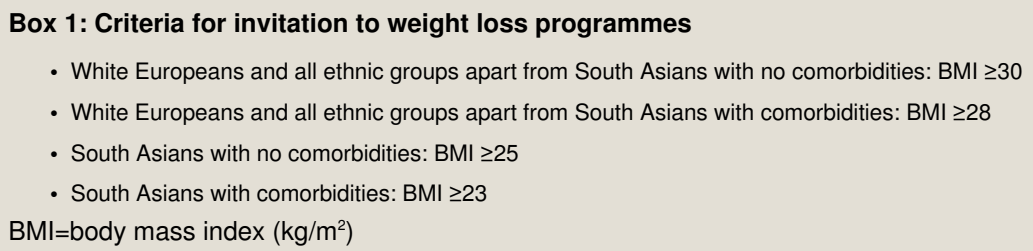

support on diet or physical activity. Box 2 gives further details of the interventions, and fuller details are online. ${ }^{12}$

\section{Data collection \\ Baseline data}

Baseline weight and height were collected when participants attended the first session of their weight loss programme or, in the case of the minimal intervention comparator, at the leisure centre. Weight was measured without shoes in light clothing. As some commercial programmes collected self reported height, height was re-measured using a Seca Leicester portable height measure at the one year follow-up. A researcher contacted participants who did not attend their first session to obtain a weight and height measurement. The call centre collected other data at baseline, before randomisation: demographic data, current physical activity levels (using the International Physical Activity Questionnaire-short form (IPAQ-short)), ${ }^{16}$ and use of weight loss drugs.

\section{Outcome assessment}

The primary outcome was weight loss at three months' follow-up (programme end). Secondary outcomes were changes in self reported physical activity, weight loss at one year, and percentage weight loss at three months and one year. Follow-up assessments took place between April 2009 and August 2010.

Attendance at the programmes, apart from the minimal intervention comparator, was reported by the individual programme providers. If participants were still attending their allocated weight loss intervention at programme end, the service providers weighed them and provided this data to the research team. We contacted participants who were no longer attending their allocated programme and offered them follow-up at home or another convenient location. If participants declined to be followed up in person, we asked them to self report their weight. The IPAQ-short was re-administered by phone to all participants at three months. We sent participants who had dropped out of their allocated programme an open ended question asking for their views about the weight loss programme to which they had been allocated.

A trained practice nurse, health trainer, or researcher blinded to the allocation group did the one year assessment at the participant's general practice or home. This included assessment of weight and height, the IPAQ-short, and a free text question about their opinion of the service and whether they had tried any other weight loss programmes or strategies over the course of the year. The scales used for weight measurement during the study period in the practices and by the weight management services were all checked with standardised weights, unless a record of recent calibration was available.

\section{Sample size}

To detect a 2 (SD 3.2) kg difference in weight loss at the three months' follow-up between any of the planned interventions and the comparator group, with $90 \%$ power and $5 \%$ significance level and assuming $20 \%$ loss to follow-up, we needed 70 participants randomised to each group. The sample size calculation did not take account of adjustments for multiple comparisons. To account for dropouts, we allocated 100 participants to each arm, except for the general practice and pharmacy arms. Because of limited availability, provision of these programmes was restricted to 70 participants per arm, resulting in a total sample size of 740 participants. We selected the $2 \mathrm{~kg}$ difference as being achievable from previous published studies, ${ }^{77}$ and an important contribution towards a 5\% weight loss, which is associated with clinically meaningful health benefits. $^{1819}$

\section{Analyses}

We did all analyses according to intention to treat and using Stata v11.0 and SPSS v17.0. We preferred objectively measured weight, but we used self reported weights when they were the only measures available. We assumed participants for whom weight at follow-up was not available to have their baseline weight for the primary analyses. We also did a sensitivity analysis using the last recorded weight as the follow-up weight.

For the outcomes measured on a continuous scale (weight loss, self reported physical activity), we investigated differences between the seven intervention groups and the minimal exercise comparator group by using least squares linear regression. Between group analyses are expressed as both unadjusted and adjusted differences (corrected for baseline score for weight and physical activity, age, sex, and ethnicity). To adjust for multiple analyses, we applied a Bonferroni correction to each pair-wise comparison between intervention and control to maintain a 5\% type I error rate across the seven comparisons made. A secondary pre-specified analysis compared the outcomes of the commercial weight loss programmes (Weight Watchers, Slimming World, and Rosemary Conley) with those of the primary care programmes (general practice and pharmacy based interventions), as these programmes are widely generalisable. This analysis adjusted for the clustering of patients within their allocated treatment groups.

We present the proportions of each group that achieved at least $5 \%$ weight loss at programme end and one year descriptively. We examined the effect of choosing a weight loss programme over being allocated to one by using a regression model that compared the programme randomised or chosen with the minimal intervention comparator but additionally included a single term to assess whether having chosen the programme had an additional beneficial effect over being randomised to the programme. We extended the model to examine whether any interaction existed between individual programmes and choice. In an exploratory subgroup analysis, we examined weight loss separately in men and women by using a regression model, with the arm to which they were allocated and age as covariates. Furthermore, we examined whether the effects of each intervention varied by sex by adding multiplicative interaction terms for intervention by sex to the model. This is because commercial weight loss interventions are almost invariably run by women and treat their clients in groups dominated by women, so the effectiveness might vary by sex. 


\section{Box 2: Brief description of interventions}

Weight Watchers is group based, and the participant was able to join at any time. One to one support is available for new members and during weighing. This is followed by a group talk from the leader, with discussion. Meetings took place in community venues and lasted one hour. Core programme material delivered over five weeks included a food points system (based on age, sex, height, weight, and activity), beating hunger, taking more physical activity, eating out, and keeping motivated. Other sessions delivered to the whole group covered recipes, health and nutrition, and keeping active. The plan aims for $500 \mathrm{kcal}(2.09 \mathrm{MJ})$ deficit/day, leading to $0.5-1.0 \mathrm{~kg}$ weight loss a week Physical activity is encouraged; the objective is to gradually build up to 10000 steps daily. Predominant strategies used to change behaviour included stages of change, food and activity diaries, goal setting, and evaluation of progress. Rewards are given for every $3.2 \mathrm{~kg}(7 \mathrm{lb})$ lost and for loss of $5 \%$ and $10 \%$ of body weight.

Slimming World is group based, and the participant was able to join at any time. Meetings took place in community venues and lasted 90 minutes. Also included is access to a website, magazines, and one to one telephone support from a consultant or other members. Members are encouraged to eat mainly foods with low energy density to achieve satiety, plus some extras rich in calcium and fibre, with controlled amounts of high energy dense foods. Weight loss goals are set by the individual. Physical activity is encouraged, with gradual build up to 30 minutes of moderately intense activity five days a week. The theoretical background is based on transactional analysis and motivational interviewing. Predominant behaviour change strategies used included weekly weighing; group support; and group praise for weight loss, new decisions, and continued commitment even in the absence of weight loss. Awards are given for $3.2 \mathrm{~kg}(7 \mathrm{lbs})$ lost and loss of $10 \%$ of body weight. Individual support, if needed, uses self monitoring of food and emotions, for and against evaluations, visualisation techniques, and personal eating plans.

Rosemary Conley is group based, and the participant was able to join at any time. Meetings took place in community venues and lasted 90 minutes. One to one support is offered during weighing and to establish a calorie allowance. Additional support is available by email and telephone. Goals are staged: either $1-1.5 \mathrm{~kg} /$ week with a goal of $6.35 \mathrm{~kg}$ (1 stone) loss or $0.5-1 \mathrm{~kg} / \mathrm{week}$ with an initial goal of $3.2 \mathrm{~kg}(7 \mathrm{lb})$. Sessions include a 45 minute optional exercise class. Extra exercise sessions may be offered for an additional fee. The theoretical background is based on role modelling and group support and uses visualisation and reframing to support behavioural change. Predominant behaviour change strategies used include rewards for slimmers who maintain or lose weight, slimmer of the week, and certificates for $3.2 \mathrm{~kg}$ and 6.35 kg milestones.

The Size Down Programme was an NHS group based programme run in community venues by support workers trained by the dietetics service. This provided six weekly two hour sessions, with follow-up sessions at nine and 12 weeks. All participants joined together in week one of the programme. Its particular focus was on long term changes in patterns of eating behaviour, achieving a balanced diet, and increasing physical activity in daily life, and it used an interactive style. Topics covered included managing behaviour around food and prevention of relapse, the eatwell plate, nutritional information, planning strategies to deal with lapses into previous dietary behaviours, interactive visual aids to show the fat and sugar content of foods, and adaptation of recipes. The theoretical background was based on the cycle of change (Prochaska and Di Clemente). The benefits of physical activity, setting goals, and finding activities to fit into life were discussed. Predominan behaviour change strategies used included goal setting, stages of change, and self monitoring with a food diary.

The general practice and pharmacy programmes comprised 12 one to one sessions in the general practice or pharmacy. The first session was planned to last 30 minutes, with follow-up sessions of 15-20 minutes. Sessions were client led and based around a problem solving approach. Sessions included weight and dieting history, exploration of goals and expectations of patients, the eatwell plate, setting goals to reduce calorie intake and increase physical activity, planning strategies to deal with challenging situations, use of food diaries, and maintaining weight loss. Weight loss goals were $5-10 \%$ of starting body weight, at a rate of $0.5-1 \mathrm{~kg} /$ week over three to six months, followed by maintenance. Physical activity goals were to aim to slowly increase activity levels to achieve 30 minutes of moderate activity on five days each week. The theoretical basis used stages of change and motivational interviewing. Predominant behaviour change strategies included goal setting, self monitoring with food diaries, hunger scale, waist measurements, and physical activity. Resources were provided as homework for discussion in the next session or for personal reflection. Participants were encouraged to reward themselves for success.

\section{Costs}

We ascertained the price to the primary care trust of each programme and of sending out invitation letters from practices. We calculated the cost of the call centre that coordinated the service as an average per person, based on the cost of staff employed over a 12 month period and the number of clients who used the service over this time period.

\section{Results}

Of the 8810 people invited, 1011 (11.5\%) joined the Lighten Up service (740 as part of the trial and a further 271 in a pilot or after recruitment to the trial had finished). At programme end, 658 (88.9\%) participants were followed up; 522 (70.5\%) were followed up at one year (fig $1 \Downarrow$ ). Table $1 \Downarrow$ shows the baseline characteristics of participants. Participants who were lost to follow-up at programme end tended to be younger than those who were followed up, but they were similar in terms of body mass index at the start of the programme, sex, ethnicity, and index of multiple deprivation score.

\section{Weight loss at programme end}

The primary outcome of weight change at programme end was available for 587 (79.3\%) participants, of which 233 (39.7\%) weights were self reported. All programmes, including the minimal intervention comparator group, achieved statistically significant weight loss from baseline to the three month end of programme, with the mean weight loss ranging from 4.4 (SD 4.3) $\mathrm{kg}$ (Weight Watchers) to 1.4 (4.1) kg (general practice provision) in the primary analysis (missing data imputed with baseline value) (table $2 \Downarrow$ ). In the between group analyses, only the commercial providers (Weight Watchers and Rosemary
Conley) had a statistically significantly greater weight loss and percentage weight loss than the exercise only comparator (tables $3 \Downarrow$ and $4 \Downarrow$ ). The findings did not differ when we adjusted the results for baseline weight, age, sex, or ethnic group. In the sensitivity analysis (with last recorded value used to impute missing data), the arm randomised to Slimming World also achieved a statistically significantly greater weight loss than the minimal intervention comparator in the unadjusted analysis (web appendix). The proportion of participants in each arm who achieved at least $5 \%$ weight loss at programme end ranged from $16 \%$ to $46 \%$ (between general practice and Weight Watchers) (table $5 \Downarrow$ ).

\section{Weight loss at one year}

At one year, follow-up weight was recorded for 503 (68\%) participants, of which 87 (17.3\%) weights were self reported. Statistically significant weight loss from baseline to one year follow-up occurred in all groups apart from those in the primary care arms (general practice and pharmacy) (table $2 \Downarrow$ ). In the between group analyses, only the Weight Watchers arm achieved a statistically significantly greater weight loss and percentage weight loss than the exercise only comparator (tables $3 \Downarrow$ and $4 \Downarrow$ ). These findings did not differ in the sensitivity analyses, when the last recorded weight was used in the imputation (web appendix). The proportion of participants in each arm who achieved at least 5\% weight loss at one year ranged from $14 \%$ to $31 \%$ (between pharmacy and Weight Watchers) (table $5 \Downarrow$ ). At one year, $449(60.7 \%)$ of the sample provided information about whether they were still trying to lose weight. Of these, 177 (39\%) respondents reported continuing to use the weight loss methods learnt from the programme they were allocated to; the highest proportions were from those allocated to Size 
Down $(\mathrm{n}=29 ; 53 \%)$ and Weight Watchers $(34 ; 45 \%)$. The participants who reported continuing to use the methods from their allocated weight loss programme had lost weight $(0.57$ (5.6) $\mathrm{kg}$ ) from programme end to the one year follow-up, whereas those who had changed to another method had gained 1.17 (5.6) $\mathrm{kg}$ and those who had stopped trying to lose weight had gained $1.18(6.0) \mathrm{kg}(\mathrm{P}=0.01)$.

\section{Per protocol analyses}

To determine the weight loss in more adherent participants, we did a post hoc analysis of weight loss at programme end and at one year in participants who had started their programme $(n=599)$. Within group weight loss was slightly higher than for the whole sample but retained the same differences between the study arms. At programme end, with baseline observation carried forward, the general practice participants still had the lowest weight loss from baseline (1.91 (95\% confidence interval 0.86 to 2.96$) \mathrm{kg}$ ) and Weight Watchers had the largest weight loss $(4.83(3.97$ to 5.70$) \mathrm{kg})$. We saw a similar picture at one year.

\section{Effect of choice}

In the choice arm, $71(71 \%)$ participants chose one of the commercial providers (Weight Watchers 29 (29\%), Slimming World 14 (14\%), Rosemary Conley 28 (28\%)), 16 (16\%) chose the Size Down programme, $3(3 \%)$ chose general practice, and $10(10 \%)$ chose pharmacy provision. Women were more likely than men to choose one of the commercial providers (57 (81\%) $v 14(47 \%))$.

We found no statistically significant difference in weight loss achieved at programme end or one year follow-up between participants who chose their programme and those who were randomised to the same programme (adjusted mean difference 0.19 (95\% confidence interval -0.7 to 1.1$) \mathrm{kg}$ at programme end and 0.01 ( -1.3 to 1.3$) \mathrm{kg}$ at one year. We found no statistically significant interaction between choice and programme.

\section{Effect of sex}

In adjusted models, sex had no effect on weight loss at programme end or one year. Nor did we find any statistically significant interaction between sex and the weight loss programme.

\section{Commercial programmes versus one to one primary care programmes}

In the pre-specified secondary analysis comparing the commercial programmes with the primary care programmes, participants randomised to the commercial programmes lost 2.3 (1.3 to 3.4$) \mathrm{kg}$ more than did those allocated to the primary care programmes at programme end $(\mathrm{P}=0.004)$. In the analysis adjusted for age, ethnicity, sex, weight, and physical activity at baseline, the additional weight loss in the commercial groups was 2.3 (1.3 to 3.4) $\mathrm{kg}$. At one year, the difference was $1.7(0.5$ to 3.0$) \mathrm{kg}(\mathrm{P}=0.02)$ unadjusted and $1.6(0.3$ to 2.9$) \mathrm{kg}(\mathrm{P}=0.06)$ in the adjusted model. Mean weight loss at one year, with baseline value used for imputation, was 0.8 (SD 4.7) $\mathrm{kg}$ for primary care and 2.5 (6.2) $\mathrm{kg}$ for commercial programmes.

\section{Self reported physical activity}

Self reported physical activity increased between baseline and follow-up in all groups (table $2 \Downarrow$ ). The smallest increase in activity was in those allocated to the general practice arm. When we compared the change in physical activity with that in the comparator group at programme end, only the pharmacy group reported statistically significantly more activity in the unadjusted analysis. At one year follow-up, only participants allocated to Weight Watchers reported more activity than the comparator group, although this was not statistically significant. Those allocated to the general practice arm were doing statistically significantly less physical activity than the comparator group (table $6 \Downarrow$ ).

\section{Attendance at programmes}

Figure $2 \Downarrow$ shows the attendance at the programmes. The pharmacy and general practice groups had the highest proportions of participants attending less than $25 \%$ of sessions $(54 \%(\mathrm{n}=38)$ and $44 \%(31))$, whereas Weight Watchers and the choice groups had the highest proportions attending $50 \%$ or more sessions (70\% (70) and 74\% (74)). In the open ended feedback, 10 participants allocated to Rosemary Conley reported difficulties with completing the exercise part of the classes owing to arthritis and other musculoskeletal problems.

\section{Costs}

Table $7 \Downarrow$ shows the costs of the programmes. These include the costs of the provider's service and the cost of the searches in general practice, invitation letters, and provision of call centre support.

\section{Discussion}

For our primary outcome of weight loss at programme end, although all the interventions resulted in a significant weight loss from baseline, only participants in the commercially run programmes (Weight Watchers and Rosemary Conley) had significantly greater weight loss than did those in the comparator group. At one year follow-up, participants in all the programmes apart from the one to one programmes in primary care and pharmacy settings had a significant weight loss from baseline, but only those allocated to Weight Watchers had a significantly greater loss than the comparator group. Attendance seemed to be an important factor; the highest attendance rate was in Weight Watchers and the lowest for the primary care programmes.

\section{Meaning of findings}

Although interventions varied in the emphasis that they placed on physical activity, all groups showed some increase in physical activity. The typical participant did no moderate or vigorous activity (which does not include walking) at baseline and was doing 50-60 minutes a week at 12 weeks and about half that at one year follow-up. Those in the exercise only comparator group were doing a similar amount to participants in other arms. All interventions therefore seemed to act as a spur for people to do what they already knew they should be doing, a conclusion that is supported by qualitative feedback from participants (data not shown). This activity was probably insufficient to account for weight loss in the comparator group, and this weight loss probably represents what might be achieved by people responding to a spur to action. We believe that the comparator group was therefore a true control group. The comparator group achieved statistically significant weight loss from baseline to follow-up at both programme end and one year. This is probably a reflection of the motivation of those people who accepted the invitation to the weight loss programme. A meta-analysis of cohort studies showed that over four years of follow-up, obese people lose weight. ${ }^{20}$ The weight loss in our comparator group was only slightly greater than this "natural" weight loss observed in cohorts receiving no intervention. It is presumably a result 
of efforts by people to lose weight, most of which are unaided by specific interventions.

Our study shows that 12 week weight management courses are effective in producing clinically significant weight loss in a proportion of their clients. Almost a third of people allocated to the Weight Watchers group achieved a clinically important $5 \%$ reduction in body weight at one year follow-up. This level of weight loss has been shown to reduce the risk of progression to diabetes. ${ }^{18}{ }^{19}$ Other trials of commercial providers have shown greater weight loss, but these interventions were of longer duration. ${ }^{51}$ In a trial in the United Kingdom, Germany, and Australia, Jebb reported a $4.0 \mathrm{~kg}$ average weight loss after a one year Weight Watchers programme, ${ }^{21}$ which is only marginally greater than the 3.5 (SD 6.9) $\mathrm{kg}$ loss we found at one year as a result of a 12 week programme. In the United States, Heshka and colleagues reported that one year's free access to Weight Watchers resulted in a weight reduction of $3.5 \mathrm{~kg}$ at one year. ${ }^{5}$ Truby and colleagues evaluated a six month programme in a volunteer sample recruited from a national media campaign and reported a 6.6 (SD 5.4) kg loss in those allocated to Weight Watchers and a $6.3(6.1) \mathrm{kg}$ loss in those allocated to Rosemary Conley at the six month follow-up. ${ }^{7}$ At one year, data were available only for completers, but with baseline observation carried forward the mean weight loss was $4.6 \mathrm{~kg}$ for the Weight Watchers and $5.3 \mathrm{~kg}$ for the Rosemary Conley groups. The greater weight loss in these trials suggests that longer interventions might be somewhat more effective.

We did not find statistically significant benefits from the programmes in primary care. The Counterweight Project Team reported promising results from their weight management programme in primary care in the $\mathrm{UK},{ }^{8-10}$ but this was not a randomised trial. Using baseline observation carried forward, the mean weight loss at one year in the Counterweight programme was $1.3 \mathrm{~kg}$, which is slightly greater than the 0.8 $\mathrm{kg}$ we report. Hardcastle and colleagues reported statistically significant weight loss at six months' follow-up in a randomised controlled trial of a primary care based weight loss programme compared with a no intervention control, with weight loss of $0.7 \mathrm{~kg}$, similar to our findings. ${ }^{22}$ Lower weight loss in general practice or pharmacies may be due to several factors. Firstly, although the primary care practitioners were trained in weight management counselling before the start of Lighten Up, they had considerably less experience of weight management than did counsellors/group leaders of other programmes, and this is one of a multitude of other roles they have in primary care.

Secondly, primary care and pharmacy sessions were one to one and the dynamic of the group may be an important element in supporting successful weight loss. ${ }^{23}$ Thirdly, feedback from participants who did not complete the full programme suggested that they had difficulties in arranging convenient sessions so these often did not occur on a weekly basis, unlike the commercial programmes, which occur weekly at a regular time. Finally, some evidence suggests that primary care practitioners have little faith in their ability to effect positive change in their patients' weight. ${ }^{24}$ Analogous data from smoking cessation programmes show that primary care based services are less effective than dedicated cessation services. ${ }^{25} 26$ This could indicate a generic problem with supporting behavioural change in primary care that needs further investigation.

The proportions of recruited participants who did not start the programmes varied considerably between the study groups. This may well be related to the process for taking up the intervention. In the primary care programmes and minimal intervention comparator, participants were provided with details about how to make their first appointment, whereas for the commercial programmes participants were booked directly on to a programme and provided with details of the venue and time of their first session. The Size Down group was a closed group in which all participants started together, so some people had to wait several weeks before a new group started. This may have accounted for the high proportion who did not start this programme. This has implications for the planning of future similar programmes.

Concerns have been raised about whether the commercial programmes are acceptable to men, as they are generally run by and attended by women. ${ }^{21}$ As with other weight loss trials, ${ }^{57-102122}{ }^{27}$ we had more female participants, so men seem to be less likely to accept the offer of this form of help. However, we found no evidence that outcomes were worse for men attending the commercial group based programmes. We did assign some of the commercial groups as "male friendly" so that men would know that there would be other male attendees, and in the case of a Rosemary Conley class a group walk was available as an alternative to the group exercise session. Men in the choice arm were more likely to select the NHS programmes, including the group based Size Down programme, possibly because of the female image of the commercial programmes, although almost half did select a commercial programme.

Two previous weight loss trials have investigated the effect of being allocated a choice of intervention. Burke and colleagues randomised participants either to choose one of two dietary regimens or to have this allocated randomly. ${ }^{28}$ The diets were equally effective in promoting weight loss, but people randomly allocated to a diet achieved significantly greater weight loss than did those allocated to choose their preferred diet (about $3.5 \mathrm{~kg}$ greater at 18 months). Renjilian and colleagues randomised participants to either choose between individual and group treatment for weight loss or be allocated the treatment modality that they did not prefer. ${ }^{23}$ The trial showed that group treatment was more effective than one to one treatment, but the differences in weight loss between those randomised to choice and those randomised to receive the modality they did not choose were small and non-significant. Taken together with our results, these data indicate that choice of treatment programme is not important in the efficacy of weight management programmes. As long as people are prepared to participate, they will probably benefit. Promoting choice in health interventions risks promoting less effective options, as happened here in the Lighten Up trial. People seem to be unable to choose a programme for weight management that is more effective for them than one simply allocated at random.

To illustrate the potential importance to public health of the effects of the commercial weight loss interventions, we constructed a life table. Firstly, we calculated the age and sex specific mortality rates for people of ideal body mass index from published UK data (available from the authors). Secondly, we applied the hazard ratio for an increase to a body mass index of 34 (the mean of our trial population). ${ }^{29}$ We then used these rates to produce a life table from age 49 years (the mean age in the trial). In the most effective intervention, participants lost $1.3 \mathrm{~kg} / \mathrm{m}^{2}$ on average, and we recalculated the life table on the basis of this reduced body mass index. The difference in life expectancy was about one year. If we assumed that the people randomised to this intervention continued to weigh $1.3 \mathrm{~kg} / \mathrm{m}^{2}$ less throughout life, then the cost per life year saved was about $£ 77$ ( $888 ; \$ 122$ ). These benefits are not discounted and make many assumptions, but they illustrate that this intervention could be very cost effective, with the critical factor being duration of maintenance of weight loss. A two year study of a commercial 
programme showed minor weight regain in the second year, but the intervention was available to participants during that time. ${ }^{5}$ More intensive interventions on weight loss in the diabetes prevention studies have shown a declining but small persistent advantage over 10 years for those receiving the intensive intervention, ${ }^{30}$ but whether weight loss persists from a 12 week intervention of the kind we examined is unknown. Given the potential effect on the population, this is a priority for further research, as is research on prevention of weight regain.

\section{Strengths and limitations of study}

This trial was an evaluation of a range of weight management programmes in a real service context, and we have shown that robust evaluation of new services is possible. We kept data collection to a minimum to encourage people to take part, thus increasing the generalisability of the results. However, unlike most other trials, ${ }^{7-10}{ }^{21}$ we have measured self reported physical activity to determine the contribution this makes to weight loss. The population was more diverse than in many previous trials ${ }^{8-101731} ; 13 \%$ of the sample were from an ethnic minority group, more than $30 \%$ were men, and $73.4 \%$ were from the two most socioeconomically disadvantaged fifths of the population. The characteristics of our recruited participants reflect the population of the primary care trust well; $23.5 \%$ of the participants were in the bottom $10 \%$ of socioeconomic deprivation, which is similar to that for the primary care trust, and the $13 \%$ of participants from a minority ethnic group is slightly lower than the local prevalence of $18 \%$. In one practice for which data were available, we investigated how the characteristics of people who were invited differed from those who joined the study. We found no difference in ethnicity, mean age, or socioeconomic deprivation, but, as expected, women were more likely to accept the invitation to take part. Our follow-up rates at one year compare well with other studies of weight management interventions, which reduced bias from attrition.-1021

Our trial has some limitations. It was powered only to compare individual programmes with the comparator group, not to make head to head comparisons between programmes. Where we were unable to get an objective weight measurement, we asked participants to self report. However, we do not believe that this will have led to overestimation of weight loss, as those who self reported their weight at the time of predicted programme end had a smaller weight loss than did those who provided an objective measure of weight, but some measurement error may exist. The self reported physical activity seems high and, as reported previously, ${ }^{32}{ }^{33}$ is likely to be an overestimate. However, as we had baseline measures, we are able to present change in activity, and differences in overestimation between trial arms are unlikely. To increase the uptake and follow-up rates, we kept data collection to a minimum, so we do not have data on health outcomes or on the previous strategies for weight loss used by the participants. The response rate to the invitation was $11.5 \%$. These are likely to be people who were most motivated to change. Invitation was by post, and a face to face invitation in the context of a consultation might result in higher uptake of the service. Attendance data were provided by the providers of the weight management programmes and could not be independently validated, so they may be subject to some errors. The costs that we present are the direct costs of the programme to the primary care trust; we have not tried to determine cost to primary care from a change in consultation rates or drugs or the costs to the participants of attending the programmes or purchasing any products from the commercial programmes. We could not unpick the elements associated with greater weight loss in people who attended the commercial programmes. This might have been due to the group based approach, the skills and background of the group leaders, the regularity of sessions, or easy booking for the first session and no scheduling requirements thereafter.

\section{Conclusion}

Our findings suggest that a 12 week group based dedicated programme of weight management can result in clinically useful amounts of weight loss that are sustained at one year in an unselected primary care population with obesity. Interventions provided by primary care showed no evidence of effectiveness. The only programme to achieve statistically significantly greater weight loss than the comparator group was Weight Watchers. Further research should explore the optimal duration of such programmes.

Contributors: JD and JB designed the Lighten Up service. $\mathrm{KJ}, \mathrm{AD}$, PAveyard, JD, JB, and PAdab designed the study and wrote the initial protocol. KJ, AL, AD, PAveyard, JD, JB, and PAdab were on the trial management committee. AL coordinated the study with supervision from KJ. JJD and KJ did the analysis. KJ drafted the manuscript with contributions from the other authors. PAveyard did the years of life lost analysis. All authors read and approved the final manuscript. $\mathrm{KJ}$ is the guarantor.

Funding: The study was funded by NHS South Birmingham. PAveyard is supported by a National Institute for Health Research (NIHR) career scientist award. AD is supported by a senior research fellowship award from the NIHR. KJ was part funded by the NIHR through the Collaborations for Leadership in Applied Health Research and Care for Birmingham and Black Country (CLAHRC-BBC) programme. The views expressed in this publication are those of the authors and not necessarily those of the NIHR, the Department of Health, NHS South Birmingham, the University of Birmingham, or the CLAHRC-BBC Steering Group. JD and JB were employed by the sponsoring organisation. Their roles are outlined above. The writing of the report and the decision to submit the article for publication rested with the authors from the University of Birmingham.

Conflicts of interest: All authors have completed the ICMJE uniform disclosure form at www.icmje.org/coi_disclosure.pdf (available on request from the corresponding author) and declare: PAveyard and $A L$ have received hospitality from Weight Watchers on one occasion; JD and JB were employed by the funding organisation and managed the service.

Ethical approval: South Birmingham Research Ethics Committee (08/H1207/331) granted ethical approval.

Data sharing: Additional data can be obtained from the corresponding author for the purposes of secondary research.

1 World Health Organization. Obesity. 2011. www.euro.who.int/en/what-we-do/health-topics/ noncommunicable-diseases/obesity.

2 Kopelman P. Health risks associated with overweight and obesity. Obes Rev 2007;8(suppl 1):13-7.

3 Craig R. Physical activity and fitness: summary of key findings. In: Mindell J, Hirani V, eds. Health Survey for England 2008. NHS Information Centre, 2009.

4 National Institute for Health and Clinical Excellence. Obesity: guidance on the prevention, identification, assessment and management of overweight and obesity in adults and children. NICE, 2006 (clinical guideline 43)

5 Heshka S, Anderson JW, Atkinson RL. Weight loss with self-help compared with a structured commercial program: a randomized trial. JAMA 2003;289:1792-8.

6 Rock CL, Pakiz B, Flatt SW, Quintana L. Randomized trial of a multifaceted commercial weight loss program. Obesity 2007;15:939-49.

7 Truby H, Baic S, deLooy A, Fox KR, Livingstone MBE, Logan CM, Macdonald IA, et al. Randomised controlled trial of four commercial weight loss programmes in the UK: initial findings from the BBC "diet trials". BMJ 2011;332:1309-14.

8 Counterweight Project Team. A new evidence-based model for weight management in primary care: the Counterweight Programme. J Hum Nutr Dietet 2004;17:191-208.

9 Counterweight Project Team. Empowering primary care to tackle the obesity epidemic: the Counterweight Programme. Eur J Clin Nutr 2005;59(suppl 1):S93-101.

10 Counterweight Project Team. Evaluation of the Counterweight Programme for obesity management in primary care. Br J Gen Pract 2008;58:548-54 


\section{What is already known on this topic}

Some commercial and primary care based weight management programmes have been shown to produce significantly greater weight loss than in a control group after one year

\section{What this study adds}

In a primary care population, group based programmes produced significant weight loss at one year after a 12 week programme One to one primary care based programmes were ineffective and most costly to provide Short commercial and NHS group based programmes have the potential to produce clinically useful weight loss at one year follow-up

11 Moore H, Summerbell CD, Greenwood DC, Tovey P, Griffiths J, Henderson M, et al. Improving management of obesity in primary care: cluster randomised trial. $B M$ 2003;327:1085.

12 Jolly K, Daley A, Adab P, Lewis A, Denley J, Beach J, et al. A randomised controlled trial to compare a range of commercial or primary care led weight reduction programmes with a minimal intervention control for weight loss in obesity: the Lighten Up trial. BMC Public Health 2010;10:439 (available at www.biomedcentral.com/1471-2458/10/439).

13 Weight Watchers. How Weight Watchers works. 2011. www.weightwatchers.co.uk/plan apr/index.aspx.

14 Slimming World. Slimming with support: information for health professionals. Slimming World, 2011.

15 Rosemary Conley. Tackling obesity—NHS GP referral scheme. 2011. www. rosemaryconley.com/content/slim-at-classes/working-with-the-nhs.htm.

16 Craig CL, Marshall AL, Sjöström M, Bauman AE, Booth ML, Ainsworth BE, et al. International physical activity questionnaire: 12 -country reliability and validity. Med $\mathrm{Sc}$ Sports Exerc 2003;35:1381-95.

17 Lavin JH, Avery A, Whitehead SM, Rees E, Parsons J, Bagnall T, et al. Feasibility and benefits of implementing a slimming on referral service in primary care using a commercial weight management partner. Public Health 2006;120:872-81.

18 Diabetes Prevention Program Research Group. Reduction in the incidence of type 2 diabetes with lifestyle intervention or metformin. N Engl J Med 2002;346:393-403.

19 Tuomilehto J, Lindstrom J, Eriksson JG, Valle TT, Hämäläinen H, Ilanne-Parikka P, et al. Prevention of type 2 diabetes mellitus by changes in lifestyle among subjects with impaired glucose tolerance. N Engl J Med 2001;344:1343-50.

20 Prospective Studies Collaboration. Body-mass index and cause specific mortality in 90 000 adults: collaborative analyses of 57 prospective studies. Lancet 2009:373:1083-96.

21 Jebb SA, Ahern AL, Olson AD, Aston LM, Holzapfel C, et al. Primary care referral to a commercial provider for weight loss treatment versus standard care: an international randomised controlled trial. Lancet 2011;378:1485-92

22 Hardcastle S, Taylor A, Bailey M, Castle R. A randomised controlled trial on the effectiveness of a primary health care based counselling intervention on physical activity, diet and CHD risk factors. Patient Educ Couns 2008:70:31-9.

23 Renjilian DA, Perri MG, Nezu AM, McKelvey WF, Shermer RL, Anton SD. Individual versus group therapy for obesity: effects of matching participants to their treatment preferences. J Consult Clin Psychol 2001;69:717-21.

24 Leverence RR, Williams RL, Sussman A, Crabtree BF, RIOS Net Clinicians. Obesity counselling and guidelines in primary care: a qualitative study. Am J Prev Med 2007;32:334-9.
25 Aveyard P, Johnson C, Fillingham S, Parsons A, Murphy M. A pragmatic randomised controlled trial of nortriptyline plus nicotine replacement versus placebo plus nicotine replacement for smoking cessation. BMJ 2008;336:1223-7.

26 McEwen A, West R, McRobbie H. Effectiveness of specialist group treatment for smoking cessation vs. one-to-one treatment in primary care. Addict Behav 2006;31:1650-60.

27 Nanchahal K, Townsend J, Letley L, Haslam D, Wellings K, Haines A. Weight-management interventions in primary care: a pilot randomised controlled trial. Br J Gen Pract 2009;59:e157-66.

28 Burke LE, Warziski M, Styn MA, Music E, Hudson AG, Sereika SM. A randomized clinical trial of a standard versus vegetarian diet for weight loss: the impact of treatment preference. Int J Obes 2008;32:166-76.

29 Berrington de Gonzalez A, Hartge D, Cerhan JR, Flint AJ, Hannan L, Maclnnis RJ, et al. Body-mass index and mortality among 1.46 million white adults. N Engl J Med 2010;363:2211-9.

30 Diabetes Prevention Program Research Group. 10-year follow-up of diabetes incidence and weight loss in the Diabetes Prevention Program Outcomes Study. Lancet 2009;374:1677-86

31 Pagoto SL, Schneider KL, Oleski JL, Luciani JM, Bodenlos JS, Whited MC. Male inclusion in randomized controlled trials of lifestyle weight loss interventions. Obesity 2011 Jun 2 [epub ahead of print].

32 Heesch KC, van Uffelen JGZ, Hill RL, Brown WJ. What do IPAQ questions mean to olde adults? Lessons from cognitive interviews. Int J Behav Nutr Phys Act 2010;7:35.

33 Rzewnicki R, Vanden Auweele Y, De Bourdeaudhuij I. Addressing overreporting on the International Physical Activity Questionnaire (IPAQ) telephone survey with a population sample. Public Health Nutr 2003;6:299-305.

Accepted: 14 September 2011

\section{Cite this as: BMJ 2011;343:d6500}

This is an open-access article distributed under the terms of the Creative Commons Attribution Non-commercial License, which permits use, distribution, and reproduction in any medium, provided the original work is properly cited, the use is non commercial and is otherwise in compliance with the license. See: http://creativecommons.org/licenses/by$\mathrm{nc} / 2.0 /$ and http://creativecommons.org/licenses/by-nc/2.0/legalcode. 


\section{Tables}

\begin{tabular}{|c|c|c|c|c|c|c|c|c|}
\hline Characteristics & $\begin{array}{l}\text { Weight } \\
\text { Watchers } \\
(n=100)\end{array}$ & $\begin{array}{c}\text { Slimming } \\
\text { World }(n=100)\end{array}$ & $\begin{array}{c}\text { Rosemary } \\
\text { Conley } \\
(n=100)\end{array}$ & $\begin{array}{l}\text { Size Down } \\
(n=100)\end{array}$ & $\begin{array}{c}\text { General } \\
\text { practice } \\
(n=70)\end{array}$ & $\begin{array}{l}\text { Pharmacy } \\
(n=70)\end{array}$ & $\begin{array}{l}\text { Choice } \\
(n=100)\end{array}$ & $\begin{array}{l}\text { Exercise/comparator } \\
\qquad(n=100)\end{array}$ \\
\hline Male sex & $28(28)$ & $35(35)$ & $31(31)$ & $36(36)$ & $23(33)$ & $19(27)$ & $30(30)$ & $25(25)$ \\
\hline Mean (SD) age (years) & $50.71(14.56)$ & $48.84(14.91)$ & $49.76(14.51)$ & $48.75(15.63)$ & $50.48(13.79)$ & $48.94(15.82)$ & $47.45(14.35)$ & $49.67(13.83)$ \\
\hline \multicolumn{9}{|l|}{ Ethnic group: } \\
\hline White British/Irish & $87(87)$ & $88(88)$ & $83(83)$ & $91(91)$ & $63(90)$ & $61(87)$ & $83(83)$ & $84(84)$ \\
\hline South Asian & $1(1)$ & $3(3)$ & 0 & $3(3)$ & 0 & 0 & $1(1)$ & $3(3)$ \\
\hline $\begin{array}{l}\text { Black } \\
\text { British/Caribbean/African }\end{array}$ & $5(5)$ & $5(5)$ & $12(12)$ & $3(3)$ & $4(6)$ & $6(9)$ & $10(10)$ & $9(9)$ \\
\hline Mixed and other & $7(7)$ & $4(4)$ & $5(5)$ & $3(3)$ & $3(4)$ & $3(4)$ & $6(6)$ & $4(4)$ \\
\hline $\begin{array}{l}\text { Mean (SD) index of } \\
\text { multiple deprivation }\end{array}$ & $31.33(12.6)$ & $33.27(15.4)$ & $35.82(14.9)$ & $32.48(14.2)$ & $32.19(15.7)$ & $35.06(15.1)$ & $31.69(14.2)$ & 30.46 (13.9) \\
\hline $\begin{array}{l}\text { Mean (SD) starting weight } \\
(\mathrm{kg})\end{array}$ & $93.47(14.15)$ & 94.35 (13.38) & $93.72(13.68)$ & $95.47(17.88)$ & $92.04(14.75)$ & $92.81(13.71)$ & $91.72(12.49)$ & $93.14(15.13)$ \\
\hline $\begin{array}{l}\text { Mean (SD) starting BMI } \\
\left(\mathrm{kg} / \mathrm{m}^{2}\right)\end{array}$ & $33.96(3.9)$ & $33.83(3.8)$ & $33.38(3.5)$ & $33.77(3.9)$ & $33.06(3.5)$ & $33.44(3.5)$ & $33.41(3.4)$ & $33.88(4.4)$ \\
\hline \multicolumn{9}{|l|}{ Starting BMI $\left(\mathrm{kg} / \mathrm{m}^{2}\right)$ : } \\
\hline$<30$ & $12(12)$ & $11(11)$ & $17(17)$ & $14(14)$ & $11(16)$ & $9(13)$ & $14(14)$ & $14(14)$ \\
\hline $30-34$ & $51(51)$ & $51(51)$ & $49(49)$ & $51(51)$ & $39(56)$ & $35(50)$ & $54(54)$ & $48(48)$ \\
\hline $35-39$ & $29(29)$ & $32(32)$ & $27(27)$ & $27(27)$ & $18(26)$ & $20(29)$ & $28(28)$ & $25(25)$ \\
\hline$\geq 40$ & $8(8)$ & $5(5)$ & $4(4)$ & $5(5)$ & $2(3)$ & $3(4)$ & $4(24)$ & $6(6)$ \\
\hline $\begin{array}{l}\text { Median (IQR) physical } \\
\text { activity (kcals/week) }\end{array}$ & $614(0-1447)$ & $687(0-1422)$ & $386(0-1121)$ & $758(0-1565)$ & $530(0-1733)$ & $457(0-1481)$ & $571(0-1427)$ & $474(0-1168)$ \\
\hline $\begin{array}{l}\text { Median (IQR) } \\
\text { moderate/vigorous } \\
\text { physical activity } \\
\text { (minutes/week) } \\
\end{array}$ & $0(0-0)$ & $0(0-26.25)$ & $0(0-0)$ & $0(0-0)$ & $0(0-0)$ & $0(0-60)$ & $0(0-0)$ & $0(0-0)$ \\
\hline $\begin{array}{l}\text { Weight loss drug at } \\
\text { baseline }\end{array}$ & $3(3)$ & $4(4)$ & $3(3)$ & 2 (2) & $1(1)$ & $3(4)$ & $3(3)$ & $3(3)$ \\
\hline
\end{tabular}

$\mathrm{BMI}=$ body mass index; $\mathrm{IQR}=$ interquartile range. 
Table 2/ Weight loss (crude and imputed if missing), body mass index reduction, and physical activity change at programme end and one year follow-up. Values are means $(95 \% \mathrm{Cl})$

\begin{tabular}{|c|c|c|c|c|c|c|c|c|}
\hline & $\begin{array}{c}\text { Weight } \\
\text { Watchers }\end{array}$ & $\begin{array}{l}\text { Slimming } \\
\text { World }\end{array}$ & $\begin{array}{c}\text { Rosemary } \\
\text { Conley }\end{array}$ & Size Down & $\begin{array}{l}\text { General } \\
\text { practice }\end{array}$ & Pharmacy & Choice & Exercise/comparator \\
\hline \multicolumn{9}{|c|}{ Weight loss at programme end $(\mathrm{kg})$} \\
\hline BOCF† & $\begin{array}{c}4.43(3.6 \text { to } \\
5.3)^{\star \star}\end{array}$ & $\begin{array}{c}3.56(2.7 \text { to } \\
4.4)^{\star \star}\end{array}$ & $\begin{array}{c}4.23(3.2 \text { to } \\
5.2)^{\star \star}\end{array}$ & $\begin{array}{c}2.38(1.7 \text { to } \\
3.1)^{\star *}\end{array}$ & $1.37(0.4 \text { to } 2.3)^{*}$ & $\begin{array}{c}2.11(1.0 \text { to } \\
3.2)^{\star *}\end{array}$ & $\begin{array}{c}3.32(2.5 \text { to } \\
4.1)^{\star *}\end{array}$ & $2.01(1.2 \text { to } 2.8)^{\star *}$ \\
\hline $\begin{array}{l}\text { Complete } \\
\text { cases only } \ddagger\end{array}$ & $\begin{array}{c}5.15(4.2 \text { to } \\
6.1)^{\star \star}\end{array}$ & $\begin{array}{c}4.25(3.3 \text { to } \\
5.2)^{\star \star}\end{array}$ & $\begin{array}{c}5.29(4.2 \text { to } \\
6.4)^{\star \star}\end{array}$ & $\begin{array}{c}3.22(2.3 \text { to } \\
4.1)^{\star *}\end{array}$ & $2.17(0.7 \text { to } 3.7)^{\star}$ & $\begin{array}{c}2.80(1.4 \text { to } \\
4.2)^{\star \star}\end{array}$ & $3.81(2.9$ to 4.7$)$ & $2.96(1.8 \text { to } 4.1)^{\star \star}$ \\
\hline LOCF $\neq$ & $\begin{array}{c}4.71(3.9 \text { to } \\
5.6)^{\star \star}\end{array}$ & $\begin{array}{c}3.76(2.9 \text { to } \\
4.6)^{\star \star}\end{array}$ & $\begin{array}{c}4.37(3.4 \text { to } \\
5.4)^{\star \star}\end{array}$ & $\begin{array}{c}2.37(1.7 \text { to } \\
3.1)^{\star \star}\end{array}$ & $1.13(0.0$ to 2.3$)$ & $\begin{array}{c}2.14(1.0 \text { to } \\
3.2,)^{\star *}\end{array}$ & $\begin{array}{c}3.56(2.8 \text { to } \\
4.3)^{\star *}\end{array}$ & $1.87(1.0 \text { to } 2.78)^{\star *}$ \\
\hline \multicolumn{9}{|c|}{ Physical activity change to programme end (kcal/week) } \\
\hline $\mathrm{BOCF}+$ & $\begin{array}{c}1926(1225 \text { to } \\
2629)^{\star *}\end{array}$ & $\begin{array}{c}1899(1226 \text { to } \\
2571)^{\star *}\end{array}$ & $\begin{array}{c}1801(1155 \text { to } \\
2447)^{\star *}\end{array}$ & $\begin{array}{c}1480(701 \text { to } \\
2259)^{\star \star}\end{array}$ & $\begin{array}{c}1895(963 \text { to } \\
2826)^{\star *}\end{array}$ & $\begin{array}{c}2720(1790 \text { to } \\
3649)^{\star \star}\end{array}$ & $\begin{array}{c}1986(1245 \text { to } \\
2727)^{\star *}\end{array}$ & $1608,(988 \text { to } 2228)^{\star *}$ \\
\hline $\begin{array}{l}\text { Complete } \\
\text { cases only } \ddagger\end{array}$ & $\begin{array}{c}1946(1238 \text { to } \\
2654)^{\star \star}\end{array}$ & $\begin{array}{c}1957(1267 \text { to } \\
2648)^{\star \star}\end{array}$ & $\begin{array}{c}1856(1193 \text { to } \\
2520)^{\star \star}\end{array}$ & $\begin{array}{c}1542(733 \text { to } \\
2351)^{\star *}\end{array}$ & $\begin{array}{c}1980(1010 \text { to } \\
2949)^{\star *}\end{array}$ & $\begin{array}{c}2885(1912 \text { to } \\
3857)^{\star \star}\end{array}$ & $\begin{array}{c}2159(1362 \text { to } \\
2955)^{\star \star}\end{array}$ & $1747(1080 \text { to } 2415)^{\star *}$ \\
\hline \multicolumn{9}{|c|}{ Change in physical activity to programme end (minutes/week)§ } \\
\hline $\begin{array}{l}\text { Moderate and } \\
\text { vigorous }\end{array}$ & $58(42$ to 75$)$ & $60(42$ to 79$)$ & $49(33$ to 65$)$ & 55 (35 to 75$)$ & $47(25$ to 70$)$ & $73(51$ to 94$)$ & 59 (40 to 77$)$ & 51 (36 to 67$)$ \\
\hline Walking & $7(-6$ to 19$)$ & $1(-12$ to 13$)$ & $14(2$ to 26$)$ & 16 (3 to 29$)$ & $12(-4$ to 28$)$ & $1(-11$ to 14$)$ & $5(-6$ to 17$)$ & $7(-3$ to 18$)$ \\
\hline \multicolumn{9}{|c|}{ Weight loss at one year } \\
\hline BOCF† & $\begin{array}{c}3.46(2.1 \text { to } \\
4.8)^{\star \star}\end{array}$ & $\begin{array}{c}1.89(0.9 \text { to } \\
2.9)^{\star \star}\end{array}$ & $\begin{array}{c}2.12(0.9 \text { to } \\
3.4)^{\star \star}\end{array}$ & $\begin{array}{c}2.45(1.3 \text { to } \\
3.6)^{* *}\end{array}$ & $\begin{array}{c}0.83(-0.4 \text { to } \\
2.0)\end{array}$ & $\begin{array}{c}0.66(-0.4 \text { to } \\
1.7)\end{array}$ & $\begin{array}{c}2.15(0.9 \text { to } \\
3.4)^{\star *}\end{array}$ & $1.08(0.1 \text { to } 2.1)^{*}$ \\
\hline $\begin{array}{l}\text { Complete } \\
\text { cases only } \ddagger\end{array}$ & $\begin{array}{c}4.43(2.7 \text { to } \\
6.1)^{\star \star}\end{array}$ & $\begin{array}{c}3.10(1.5 \text { to } \\
4.7)^{\star \star}\end{array}$ & $\begin{array}{c}3.27(1.4 \text { to } \\
5.1)^{\star \star}\end{array}$ & $\begin{array}{c}3.71(2.0 \text { to } \\
5.4)^{\star \star}\end{array}$ & $\begin{array}{c}1.26(-0.6 \text { to } \\
3.1)\end{array}$ & $\begin{array}{c}1.19(-0.7 \text { to } \\
3.1)\end{array}$ & $\begin{array}{c}2.94(1.2 \text { to } \\
4.7)^{\star *}\end{array}$ & $1.66(0.1 \text { to } 3.2)^{*}$ \\
\hline LOCF $\ddagger$ & $\begin{array}{c}4.35(3.0 \text { to } \\
5.7)^{\star \star}\end{array}$ & $\begin{array}{c}3.28(2.2 \text { to } \\
4.4)^{\star \star}\end{array}$ & $\begin{array}{c}3.17(1.8 \text { to } \\
4.5)^{\star \star}\end{array}$ & $\begin{array}{c}3.10(1.9 \text { to } \\
4.3)^{\star *}\end{array}$ & $\begin{array}{c}1.13(-0.1 \text { to } \\
2.4)\end{array}$ & $\begin{array}{c}1.85(0.5 \text { to } \\
3.2)^{\star}\end{array}$ & $\begin{array}{c}2.96(1.7 \text { to } \\
4.3)^{\star *}\end{array}$ & $1.33(0.2 \text { to } 2.4)^{*}$ \\
\hline \multicolumn{9}{|c|}{ Physical activity change to one year (kcal/week) } \\
\hline $\mathrm{BOCF}+$ & $\begin{array}{c}2048(1262 \text { to } \\
2834)^{\star *}\end{array}$ & $\begin{array}{c}1362(645 \text { to } \\
2078)^{\star *}\end{array}$ & $\begin{array}{c}1429(657 \text { to } \\
2202)^{\star *}\end{array}$ & $\begin{array}{c}1429(644 \text { to } \\
2213)^{\star *}\end{array}$ & $\begin{array}{c}861(256 \text { to } \\
1467)^{\star}\end{array}$ & $\begin{array}{c}1473(742 \text { to } \\
2203)^{\star *}\end{array}$ & $\begin{array}{c}1642(837 \text { to } \\
2448)^{\star \star}\end{array}$ & $1766(1044 \text { to } 2487)^{\star *}$ \\
\hline $\begin{array}{l}\text { Complete } \\
\text { cases only } \ddagger\end{array}$ & $\begin{array}{c}2069(1276 \text { to } \\
2861)^{\star *}\end{array}$ & $\begin{array}{c}1404(666 \text { to } \\
2141)^{\star *}\end{array}$ & $\begin{array}{c}1473(678 \text { to } \\
2268)^{\star *}\end{array}$ & $\begin{array}{c}1488(673 \text { to } \\
2303)^{\star *}\end{array}$ & $\begin{array}{c}861(256 \text { to } \\
1467)^{\star}\end{array}$ & $\begin{array}{c}1562(792 \text { to } \\
2332)^{\star *}\end{array}$ & $\begin{array}{c}1659(846 \text { to } \\
2472)^{\star *}\end{array}$ & $1899(1129 \text { to } 2668)^{\star *}$ \\
\hline \multicolumn{9}{|c|}{ Change in physical activity to one year (minutes/week)§ } \\
\hline $\begin{array}{l}\text { Moderate and } \\
\text { vigorous }\end{array}$ & 60 (40 to 79$)$ & 21 (3 to 39$)$ & $25(10$ to 40$)$ & 19 (4 to 33$)$ & $14(-6$ to 35$)$ & 27 (3 to 51$)$ & $32(14$ to 50$)$ & $42(25$ to 60$)$ \\
\hline Walking & $-2(-15$ to 12$)$ & $-9(-22$ to 4$)$ & $-3(-8$ to 13$)$ & $7(-7$ to 21$)$ & $-12(-26$ to 3$)$ & $17(-0.4$ to 34$)$ & $-2(-14$ to 9$)$ & $-3(-14$ to 8$)$ \\
\hline \multicolumn{9}{|c|}{ Body mass index reduction at one year $\left(\mathrm{kg} / \mathrm{m}^{2}\right)$} \\
\hline BOCF† & $\begin{array}{c}1.17(0.7 \text { to } \\
1.7)^{\star \star}\end{array}$ & $\begin{array}{c}0.71(0.4 \text { to } \\
1.0)^{\star \star}\end{array}$ & $\begin{array}{c}0.75(0.3 \text { to } \\
1.1)^{\star \star}\end{array}$ & $\begin{array}{c}0.67(0.3 \text { to } \\
1.0)^{\star *}\end{array}$ & $\begin{array}{c}0.32(-0.1 \text { to } \\
0.7)\end{array}$ & $0.31(0.0$ to 0.7$)$ & $\begin{array}{c}0.90(0.5 \text { to } \\
1.3)^{\star \star}\end{array}$ & $0.45(0.1 \text { to } 0.8)^{*}$ \\
\hline $\begin{array}{l}\text { Complete } \\
\text { cases only } \ddagger\end{array}$ & $1.8(1.1 \text { to } 2.5)^{\star *}$ & $\begin{array}{c}1.36(0.7 \text { to } \\
2.0)^{\star \star}\end{array}$ & $\begin{array}{c}1.33(-0.6 \text { to } \\
2.0)^{\star *}\end{array}$ & $\begin{array}{c}1.19(0.5 \text { to } \\
1.8)^{\star *}\end{array}$ & $\begin{array}{c}0.66(-0.1 \text { to } \\
1.4)\end{array}$ & $\begin{array}{c}0.73(-0.1 \text { to } \\
1.6)\end{array}$ & $\begin{array}{c}1.42(0.8 \text { to } \\
2.1)^{\star *}\end{array}$ & $0.79(0.2 \text { to } 1.4)^{*}$ \\
\hline
\end{tabular}

BOCF=baseline observation carried forward; LOCF=last observation carried forward.

${ }^{*} \mathrm{P}<0.05$ (paired $t$ test from baseline).

${ }^{* *} \mathrm{P} \leq 0.001$ (paired $t$ test from baseline).

†Primary analysis.

¥Sensitivity analyses.

§Change from baseline in minutes/week using baseline observation carried forward. 
Table 3| Differences in weight loss at programme end and one year follow-up between intervention groups and comparator arm (exercise only)

\begin{tabular}{|c|c|c|c|c|c|c|c|c|}
\hline \multirow[b]{2}{*}{$\begin{array}{l}\text { Intervention } \\
\text { group }\end{array}$} & \multicolumn{4}{|c|}{ Programme end } & \multicolumn{4}{|c|}{ One year } \\
\hline & $\begin{array}{l}\text { Mean difference } \\
(95 \% \mathrm{Cl})\end{array}$ & $P$ value & $\begin{array}{c}\text { Adjusted mean } \\
\text { difference }^{\star}(95 \% \mathrm{Cl})\end{array}$ & $P$ value & $\begin{array}{l}\text { Mean difference } \\
\qquad(95 \% \mathrm{Cl})\end{array}$ & $P$ value & $\begin{array}{c}\text { Adjusted mean } \\
\text { difference }^{\star}(95 \% \mathrm{Cl})\end{array}$ & $P$ value \\
\hline $\begin{array}{l}\text { Weight } \\
\text { Watchers }\end{array}$ & $\begin{array}{c}-2.41(-3.60 \text { to } \\
-1.23)\end{array}$ & $<0.001$ & $\begin{array}{c}-2.34(-3.56 \text { to } \\
-1.13)\end{array}$ & 0.001 & $\begin{array}{c}-2.38(-3.98 \text { to } \\
-0.78)\end{array}$ & 0.025 & $\begin{array}{c}-2.49(-4.15 \text { to } \\
-0.83)\end{array}$ & 0.024 \\
\hline Slimming World & $\begin{array}{c}-1.55(-2.74 \text { to } \\
-0.37)\end{array}$ & 0.072 & $\begin{array}{c}-1.24(-2.47 \text { to } \\
-0.02)\end{array}$ & 0.322 & $\begin{array}{c}-0.81(-2.41 \text { to } \\
0.78)\end{array}$ & 1.000 & $-0.90(-2.57$ to 0.77$)$ & 1.000 \\
\hline $\begin{array}{l}\text { Rosemary } \\
\text { Conley }\end{array}$ & $\begin{array}{c}-2.22(-3.40 \text { to } \\
-1.04) \\
\end{array}$ & 0.001 & $\begin{array}{c}-2.39(-3.61 \text { to } \\
-1.16) \\
\end{array}$ & 0.001 & $\begin{array}{c}-1.05(-2.64 \text { to } \\
0.55)\end{array}$ & 1.000 & $-1.35(-3.03$ to 0.33$)$ & 0.798 \\
\hline $\begin{array}{l}\text { NHS Size } \\
\text { Down }\end{array}$ & $\begin{array}{c}-0.37(-1.55 \text { to } \\
0.82)\end{array}$ & 1.000 & $-0.09(-1.31$ to 1.14$)$ & 1.000 & $\begin{array}{c}-1.37(-2.97 \text { to } \\
0.23)\end{array}$ & 0.649 & $-1.65(-3.33$ to 0.04$)$ & 0.386 \\
\hline $\begin{array}{l}\text { General } \\
\text { practice }\end{array}$ & $0.65(-0.66$ to 1.95$)$ & 1.000 & $0.61(-0.73$ to 1.96$)$ & 1.000 & $0.25(-1.51$ to 2.01$)$ & 1.000 & $0.12(-1.96$ to 1.72$)$ & 1.000 \\
\hline Pharmacy & $\begin{array}{c}-0.10(-1.41 \text { to } \\
1.20)\end{array}$ & 1.000 & $0.12(-1.51$ to 1.27$)$ & 1.000 & $0.41(-1.35$ to 2.17$)$ & 1.000 & $0.06(-1.84$ to 1.96$)$ & 1.000 \\
\hline Choice & $\begin{array}{c}-1.30(-2.49 \text { to } \\
-0.12)\end{array}$ & 0.216 & $\begin{array}{c}-1.33(-2.55 \text { to } \\
-0.11)\end{array}$ & 0.224 & $\begin{array}{c}-1.07(-2.67 \text { to } \\
0.53)\end{array}$ & 1.000 & $-1.47(-3.13$ to 0.20$)$ & 0.591 \\
\hline
\end{tabular}

Negative difference favours intervention arm. P values adjusted to maintain overall $5 \%$ type 1 error rate across seven comparisons; $95 \%$ confidence intervals not adjusted.

${ }^{*}$ Adjusted for weight at baseline, physical activity at baseline, age, sex, and ethnic group. 
Table 4| Differences in percentage weight loss at programme end and one year follow-up between intervention groups and comparator arm (exercise only)

\begin{tabular}{|c|c|c|c|c|c|c|c|c|}
\hline \multirow[b]{2}{*}{$\begin{array}{l}\text { Intervention } \\
\text { group }\end{array}$} & \multicolumn{4}{|c|}{ Programme end } & \multicolumn{4}{|c|}{ One year } \\
\hline & $\begin{array}{l}\text { Mean difference } \\
(95 \% \mathrm{Cl})\end{array}$ & $P$ value & $\begin{array}{c}\text { Adjusted mean } \\
\text { difference }^{*}(95 \% \mathrm{Cl})\end{array}$ & $P$ value & $\begin{array}{l}\text { Mean difference } \\
\qquad(95 \% \mathrm{Cl})\end{array}$ & $P$ value & $\begin{array}{c}\text { Adjusted mean } \\
\text { difference }^{*}(95 \% \mathrm{Cl})\end{array}$ & $P$ value \\
\hline $\begin{array}{l}\text { Weight } \\
\text { Watchers }\end{array}$ & $\begin{array}{c}-2.53(-3.76 \text { to } \\
-1.30)\end{array}$ & $<0.001$ & $\begin{array}{c}-2.47(-3.74 \text { to } \\
-1.20)\end{array}$ & 0.001 & $\begin{array}{c}-2.58(-4.29 \text { to } \\
-0.87)\end{array}$ & 0.023 & $\begin{array}{c}-2.96(-4.47 \text { to } \\
-0.91)\end{array}$ & 0.022 \\
\hline Slimming World & $\begin{array}{c}-1.52(-2.75 \text { to } \\
-0.30)\end{array}$ & 0.106 & $-1.24(-2.52$ to 0.04$)$ & 0.408 & $\begin{array}{c}-0.88(-2.60 \text { to } \\
0.83)\end{array}$ & 1.000 & $0.98(-2.78$ to 0.81$)$ & 1.000 \\
\hline $\begin{array}{l}\text { Rosemary } \\
\text { Conley }\end{array}$ & $\begin{array}{c}-2.18(-3.41 \text { to } \\
-0.96)\end{array}$ & 0.004 & $\begin{array}{c}-2.38(-3.66 \text { to } \\
-1.09)\end{array}$ & 0.002 & $\begin{array}{c}-1.08(-2.79 \text { to } \\
0.63)\end{array}$ & 1.000 & $-1.41(-3.21$ to 0.38$)$ & 0.861 \\
\hline $\begin{array}{l}\text { NHS Size } \\
\text { Down }\end{array}$ & $\begin{array}{c}-0.17(-1.40 \text { to } \\
1.06)\end{array}$ & 1.000 & $0.04(-1.25$ to 1.32$)$ & 1.000 & $\begin{array}{c}-1.30(-3.01 \text { to } \\
0.42)\end{array}$ & 0.965 & $-1.65(-3.45$ to 0.16$)$ & 0.500 \\
\hline $\begin{array}{l}\text { General } \\
\text { practice }\end{array}$ & $0.77(-0.58$ to 2.12$)$ & 1.000 & $0.81(-0.60$ to 2.21$)$ & 1.000 & 0.21 ( -1.67 to 2.10$)$ & 1.000 & $-0.12(-2.09$ to 1.86$)$ & 1.000 \\
\hline Pharmacy & $0.00(-1.36$ to 1.35$)$ & 1.000 & $0.01(-1.44$ to 1.46$)$ & 1.000 & $0.36(-1.53$ to 2.25$)$ & 1.000 & $-0.05(-2.08$ to 1.99$)$ & 1.000 \\
\hline Choice & $\begin{array}{c}-1.39(-2.62 \text { to } \\
-0.16)\end{array}$ & 0.185 & $\begin{array}{c}-1.39(-2.67 \text { to } \\
-0.12\end{array}$ & 0.227 & $\begin{array}{c}-1.26(-2.97 \text { to } \\
0.45)\end{array}$ & 1.000 & $-1.66(-3.45$ to 0.12$)$ & 0.474 \\
\hline
\end{tabular}

Negative difference favours intervention arm. $P$ values adjusted to maintain overall $5 \%$ type 1 error rate across seven comparisons; $95 \%$ confidence intervals not adjusted.

*Adjusted for weight at baseline, physical activity at baseline, age, sex, and ethnic group. 
Table 5| Proportion of each group that achieved 5\% loss in body weight at programme end and one year follow-up

\begin{tabular}{|c|c|c|c|c|}
\hline \multirow[b]{2}{*}{ Intervention group } & \multicolumn{2}{|c|}{ Programme end } & \multicolumn{2}{|c|}{ One year } \\
\hline & Percentage $(95 \% \mathrm{Cl})$ & Relative risk $^{*}(95 \% \mathrm{Cl})$ & Percentage $(95 \% \mathrm{Cl})$ & Relative risk ${ }^{*}(95 \% \mathrm{Cl})$ \\
\hline Weight Watchers & 46.0 (36.0 to 56.3$)$ & 2.98 (1.56 to 5.66$)$ & $31.0(22.1$ to 41.0$)$ & 2.10 (1.03 to 4.28$)$ \\
\hline Slimming World & 35.0 (25.7 to 45.2$)$ & $1.56(0.81$ to 3.01$)$ & $21.0(13.5$ to 30.3$)$ & $1.22(0.57$ to 2.60$)$ \\
\hline Rosemary Conley & 42.0 (32.2 to 52.3$)$ & 2.72 (1.42 to 5.23$)$ & 26.0 (17.7 to 35.7$)$ & 1.81 (0.87 to 3.74$)$ \\
\hline NHS Size Down & 18.0 (11.0 to 26.9$)$ & 0.63 (0.30 to 1.33 ) & 21.0 (13.5 to 30.3$)$ & 1.39 (0.66 to 2.93 ) \\
\hline General practice & 15.7 (8.1 to 26.4$)$ & $0.62(0.27$ to 1.41$)$ & 15.7 (8.1 to 26.4$)$ & 0.94 (0.40 to 2.22 ) \\
\hline Pharmacy & 21.4 (12.5 to 32.9$)$ & $0.87(0.39$ to 1.94$)$ & 14.3 (7.1 to 24.7$)$ & 0.95 (0.39 to 2.30$)$ \\
\hline Choice & 35.0 (25.7 to 45.2$)$ & 1.81 (0.94 to 3.49$)$ & 28.0 (19.5 to 37.9$)$ & 2.01 (0.98 to 4.11 ) \\
\hline Exercise/comparator & 22.0 (14.3 to 31.4$)$ & 1.0 & 17.0 (10.2 to 25.8$)$ & 1.0 \\
\hline
\end{tabular}

Analyses use baseline observation carried forward.

${ }^{*}$ Adjusted for physical activity at baseline, weight at baseline, age, sex, and ethnic group. 
Table $6 \mid$ Differences in self reported physical activity at programme end and one year follow-up between intervention groups and comparator arm (exercise only)

\begin{tabular}{|c|c|c|c|c|c|c|c|c|}
\hline \multirow[b]{2}{*}{$\begin{array}{l}\text { Intervention } \\
\text { group }\end{array}$} & \multicolumn{4}{|c|}{ Programme end } & \multicolumn{4}{|c|}{ One year } \\
\hline & $\begin{array}{l}\text { Mean difference in } \\
\text { kcal/week }(95 \% \mathrm{Cl})\end{array}$ & $P$ value & $\begin{array}{c}\text { Adjusted mean } \\
\text { difference* in } \\
\text { kcal/week }(95 \% \mathrm{Cl})\end{array}$ & $P$ value & $\begin{array}{l}\text { Mean difference in } \\
\mathrm{kcal} / \text { week }(95 \% \mathrm{Cl})\end{array}$ & $P$ value & $\begin{array}{c}\text { Adjusted mean } \\
\text { difference in } \\
\text { kcal/week }(95 \% \mathrm{Cl})\end{array}$ & $P$ value \\
\hline $\begin{array}{l}\text { Weight } \\
\text { Watchers }\end{array}$ & 319 (-676 to 1314$)$ & 1.000 & 298 (-688 to 1284$)$ & 1.000 & $282(-740$ to 1304$)$ & 1.000 & 233 (-795 to 1260$)$ & 1.000 \\
\hline $\begin{array}{l}\text { Slimming } \\
\text { World }\end{array}$ & 291 (-704 to 1285$)$ & 1.000 & -299 (-694 to 1293) & 1.000 & $-404(-1426$ to 618$)$ & 1.000 & $-325(-1361$ to 710$)$ & 1.000 \\
\hline $\begin{array}{l}\text { Rosemary } \\
\text { Conley }\end{array}$ & 193 (-802 to 1188$)$ & 1.000 & $4(-1000$ to 992$)$ & 1.000 & $-336(-1359$ to 686$)$ & 1.000 & $-640(-1678$ to 398$)$ & 1.000 \\
\hline $\begin{array}{l}\text { NHS Size } \\
\text { Down }\end{array}$ & $-127(-1122$ to 868$)$ & 1.000 & $-144(-1142$ to 854$)$ & 1.000 & $-337(-1359$ to 685$)$ & 1.000 & $-258(-1299$ to 782$)$ & 1.000 \\
\hline $\begin{array}{l}\text { General } \\
\text { practice }\end{array}$ & 287 (-809 to 1383$)$ & 1.000 & 238 (-856 to 1333$)$ & 1.000 & -904 (-2031 to 222) & 0.808 & $-849(-1990$ to 292$)$ & 1.000 \\
\hline Pharmacy & 1112 (16 to 2208 ) & 0.328 & 1350 (-222 to 2479$)$ & 0.133 & $-293(-1420$ to 833$)$ & 1.000 & $-345(-1521$ to 831$)$ & 1.000 \\
\hline Choice & $378(-617$ to 1373$)$ & 1.000 & $228(-762$ to 1217$)$ & 1.000 & $-123(-1146$ to 899$)$ & 1.000 & $-254(-1285$ to 777$)$ & 1.000 \\
\hline
\end{tabular}

Positive difference favours intervention arm. P values adjusted to maintain overall $5 \%$ type 1 error rate across seven comparisons; $95 \%$ confidence intervals not adjusted.

*Adjusted for weight at baseline, physical activity at baseline, age, sex, and ethnic group. 


\section{Table $7 \mid$ Costs of interventions}

\begin{tabular}{|c|c|c|}
\hline Intervention & Provider's costs $(£)$ & Total $\operatorname{cost}^{*}(\varepsilon)$ \\
\hline Weight Watchers & 55.00 & 76.87 \\
\hline Slimming World & 49.50 & 71.37 \\
\hline Rosemary Conley & 55.00 & 76.87 \\
\hline NHS Size Down & 70.00 & 91.87 \\
\hline General practice & 90.86 & 112.73 \\
\hline Pharmacy & 90.43 & 112.3 \\
\hline
\end{tabular}

${ }^{*}$ Cost per participant recruited includes $£ 10$ for call centre, £3.54 for practices to run search of their lists and for general practitioners to screen lists for ineligible participants, and $£ 8.33$ for invitation letters sent by practices ( $£ 1$ per letter, with $12 \%$ response rate). 


\section{Figures}

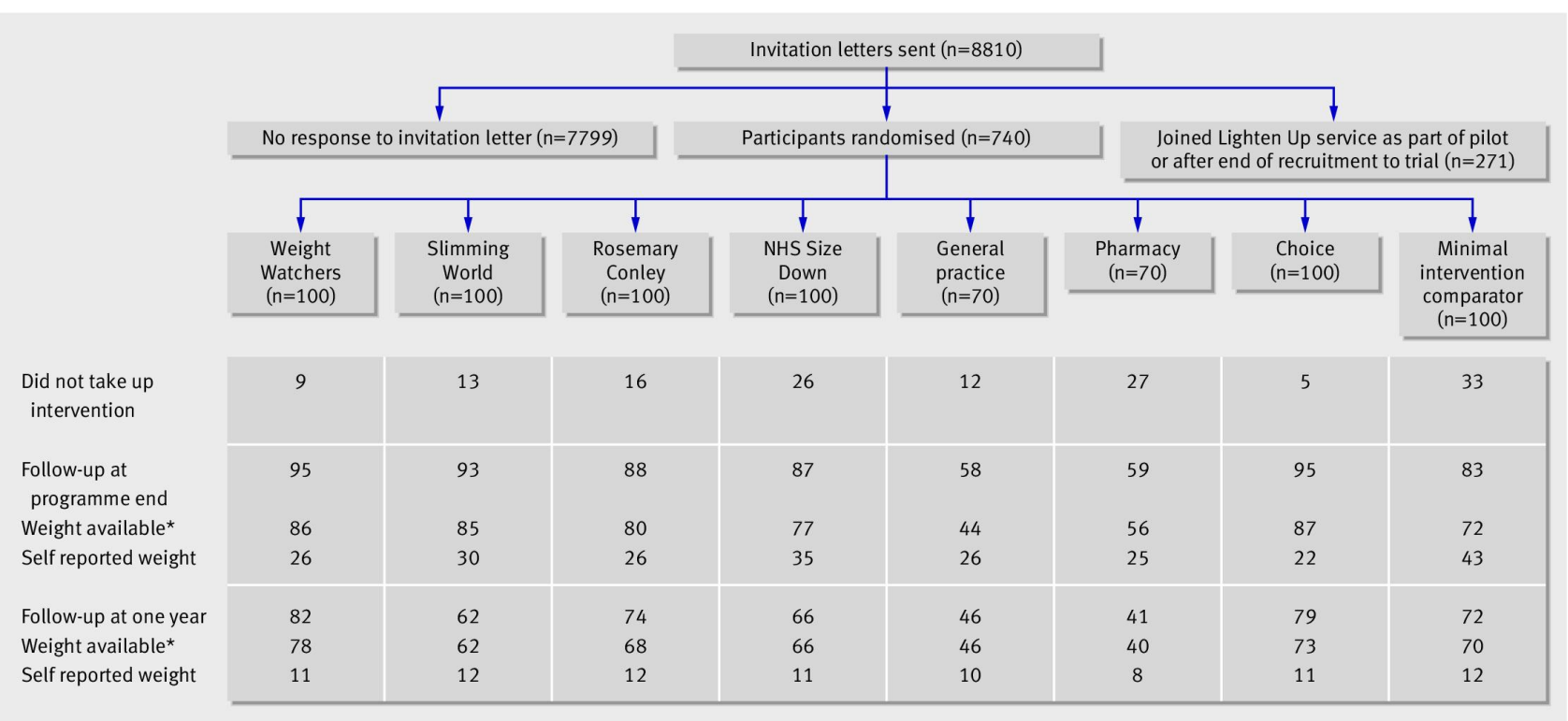

Fig 1 Flow of participants through trial. *Includes both objectively measured and self reported weight

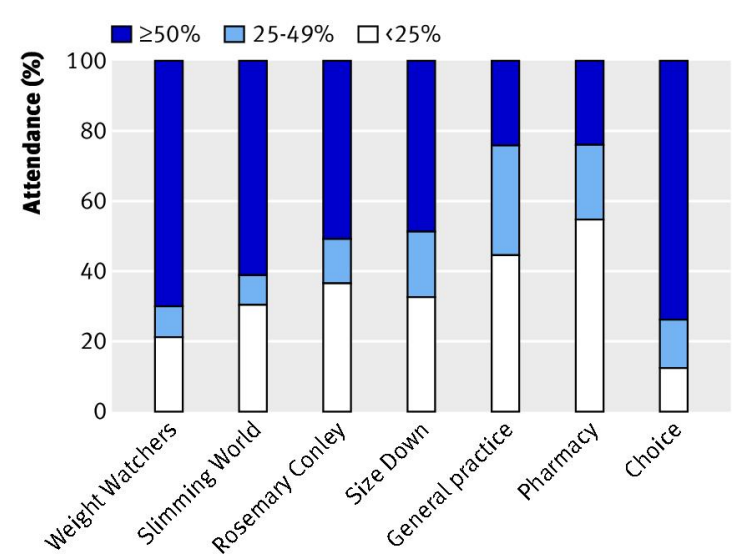

Fig 2 Proportion of scheduled weight loss programme sessions attended 